\title{
Hepatitis C infection among pregnant women in central Poland: Significance of epidemiological anamnesis and impact of screening tests to detect infection
}

\author{
Małgorzata Aniszewska ${ }^{A-F}$, Maria Pokorska-Śpiewak ${ }^{B, C, E, F}$, Barbara Kowalik-Mikołajewska ${ }^{B, E, F}$, \\ Magdalena Pluta ${ }^{\mathrm{B}, \mathrm{E}, \mathrm{F}}$, Magdalena Marczyńska ${ }^{\mathrm{E}, \mathrm{F}}$
}

Department of Children's Infectious Diseases, Medical University of Warsaw, Poland

A - research concept and design; B - collection and/or assembly of data; C - data analysis and interpretation;

$D$ - writing the article; $E$ - critical revision of the article; $F$ - final approval of the article

Address for correspondence

Małgorzata Aniszewska

E-mail:malgorzata.aniszewska@wum.edu.p

Funding sources

None declared

Conflict of interest

None declared

Received on November 14, 2016 Reviewed on December 26, 2016

Accepted on August 31, 2017

Published online on January 17, 2019

Cite as

Aniszewska M, Pokorska-Śpiewak M, Kowalik-Mikołajewska B, Pluta M, Marczyńska M. Hepatitis C infection among pregnant women in central Poland: Significance of epidemiological anamnesis and impact of screening tests to detect infection. Adv Clin Exp Med. 2019;28(3):313-318. doi:10.17219/acem/76739

DOI

10.17219/acem/76739

Copyright

Copyright by Author(s)

This is an article distributed under the terms of the

Creative Commons Attribution Non-Commercial License

(http://creativecommons.org/licenses/by-nc-nd/4.0/)

\begin{abstract}
Background. Mother-to-child transmission is one of the main sources of hepatitis ( virus (HCV) infection in children. However, because of the asymptomatic course of the illness, certain women may not be aware of their infection.
\end{abstract}

Objectives. The aim of this study was to estimate the significance of epidemiological anamnesis in diagnoses of $\mathrm{HCV}$ infection in women of reproductive age and to evaluate how screening among pregnant women impacts the detection of HCV infection.

Material and methods. Epidemiological interviews of 432 mothers infected with HCV (but free of human immunodeficiency virus (HIV)) were conducted in the Warsaw Hospital for Infectious Diseases (Poland) from 1998 to 2012.

Results. Complaints or abnormalities in laboratory tests were the reasons for anti-HCV antibody testing in $28.2 \%$ of mothers, whereas specific interview responses or occupational health care services group affiliation were the reasons for testing in 35.6\%. However, in a large group of women, infection was only detected because of screening examinations. The introduction of routine screening for pregnant women (since 2010 in Poland) has led to the increased detection of HCV infection in women who did not present with infection risk factors (9.9\% before 2010 vs $46.1 \%$ after 2010). This practice has also led to an increase in the percentage of women diagnosed during pregnancy (21.5\% before 2010 vs 30.8\% after 2010).

Conclusions. Establishing HCV infection risk factors during the interview process is the most common indicator for serological testing; however, not all infected cases can be diagnosed in this manner. Screening for anti-HCV antibodies in pregnant women increases the detection of HCV infection in this group.

Key words: pregnancy, HCV, screening, anti-HCV 


\section{Introduction}

The hepatitis $\mathrm{C}$ virus (HCV) causes an inflammation of the liver that leads to chronic disease in 50-85\% of cases. Hepatitis $C$ virus infection is usually asymptomatic or subclinical for many years; however, after 20-30 years, it can lead to cirrhosis (in 5-25\% of patients) and an increased risk of hepatocellular carcinoma. Transmission of the virus can occur during the transfusion of HCV-infected blood, the performance of medical and non-medical procedures (piercings or tattoos) using equipment contaminated with infectious material, and intravenous drug use (IVDU) with needles shared by an infected person. Infection through sexual contact with $\mathrm{HCV}$-infected persons is possible, although the risk is low. ${ }^{1-4}$ Currently, one of the main routes for $\mathrm{HCV}$ infection in children in developed countries is vertical transmission from infected mothers. Anti-HCV antibodies (anti-HCV) in pregnant women in Europe are detected at a prevalence of $0.1-1.7 \%,{ }^{5,6}$ and the risk of vertical HCV infection is estimated to be $3-10 \%{ }^{7}$ No specific methods of prevention (vaccination or specific immunoglobulin) are available to reduce the risk of transmission in children after birth. The main factor affecting vertical transmission is maternal viral load. The use of antiviral therapy before pregnancy can lead to the reduction or elimination of $\mathrm{HCV}$ vireamia. However, because of the asymptomatic nature of $\mathrm{HCV}$, women may not know they are infected. The diagnosis of $\mathrm{HCV}$ involves testing for anti-HCV (ELISA method), and a positive result is followed by an evaluation of viral replication using a reverse transcription polymerase chain reaction assay (RT-PCR).

The aims of the study were as follows: to estimate the significance of epidemiological anamnesis in diagnoses of HCV infection in women of reproductive age and to evaluate how screening among pregnant women impacts $\mathrm{HCV}$ infection detection.

\section{Material and methods}

The study group consisted of women who attended the Department of Children's Infectious Diseases (Medical University of Warsaw, Hospital for Infectious Diseases, Warszawa, Poland) in order to test for HCV infection in their infants. Epidemiological information was collected via questionnaires distributed to 432 mothers living in the Warsaw agglomeration area from 1998 to 2012. The Warsaw agglomeration is located in central Poland and it has an area of $6,200 \mathrm{~km}^{2}$ and a population of 3 million, with $80 \%$ living in the cities and $20 \%$ living in the countryside. The average prevalence in this area is 10/1,000 live births per year. The Hospital for Infectious Diseases is the primary center for diagnosis and treatment of $\mathrm{HCV}$-infected children in the agglomeration of Warszawa. The sample group of HCV-infected women were not selected using a screening population. The reasons provided for undergoing the HCV diagnostic tests were the subject of the survey. The respondent group was not homogeneous, and all women who visited the clinic to have diagnostic $\mathrm{HCV}$ tests performed on their infants were qualified for the study.

Child qualification criteria for the vertical infection tests changed over the course of this study. Between 1998 and 2009, children born to mothers with detectable anti-HCV antibodies (anti-HCV+) were tested regardless of $\mathrm{HCV}-$ RNA status. However, from 2010 to 2012, the tests were only performed on children born to anti-HCV(+) mothers that were positive for HCV-RNA - HCV-RNA(+), which resulted in a change in the recruitment of respondent mothers.

The survey questions were related to the putative source of infection, infection risk factors, and reasons for performing the diagnostic tests.

The data obtained was summarized into 3 time intervals according to the following 2 events that could have had a significant effect on the epidemiology of hepatitis $\mathrm{C}$ and the detection of HCV infection: the introduction of the RTPCR HCV-RNA test for blood donation in Poland in 2002 and the introduction of the recommended anti-HCV test for pregnant women in 2010. In the $1^{\text {st }}$ period (1998-2002), data was obtained from 54 women; in the $2^{\text {nd }}$ period (2003-2009), data was obtained from 300 women; and in the $3^{\text {rd }}$ period (2010-2012), data was obtained from 78 women. The putative sources of infection and the reasons for undergoing $\mathrm{HCV}$ infection testing were compared with respect to the women's age $(<24,25-35,>35$ years $)$ and place of residence (urban and rural). Women living in towns with more than 10,000 residents or fewer than 10,000 residents but with non-agricultural labor forces that commuted to work in larger cities were considered residents of urban areas.

The Local Ethics Committee of the Medical University of Warsaw gave its approval for the study. Each patient and/ or parents/guardians gave written informed consent for the study. The study complies with the principles outlined in the Declaration of Helsinki.

\section{Statistical analysis}

Categorical variables were compared using either the $\chi^{2}$ test or Fisher's exact test as appropriate. A p-value of $<0.05$ was considered statistically significant. All of the statistical analyses were performed using MedCalc Statistical Software v. 12.1.4.0 trial software (MedCalc, Mariakerke, Belgium).

\section{Results}

The questionnaire data on $432 \mathrm{HCV}$-infected mothers was analyzed. From 1998 to 2009, the analysis involved 354 anti-HCV(+) mothers: 182 (51.4\%) were HCVRNA(+), 59 (16.7\%) were HCV-RNA(-), and 113 (31.9\%) had an unknown HCV-RNA status. From 2010 to 2012, 
epidemiological information was gathered from 78 women: 59 (75.6\%) were HCV-RNA(+) and 19 (24.4\%) had an unknown HCV-RNA status (children who were adopted and in foster families (biological mother unavailable)). Epidemiological data on the mothers of adopted children was obtained from the children's medical records. Almost all of the women (431/432) were Caucasian (427 of Polish nationality and 4 of Ukrainian nationality), while 1 woman was Asian. The average age of the mothers was 29.85 years (range: 18-50), including 37 women younger than 24 years, 346 women between 24-35 years of age, and 49 women older than 35 years. In addition, 367 women (85\%) lived in urban areas and 65 women (15\%) lived in rural areas.

Events in the women's history that might have increased the risk of HCV infection are presented in Table 1.

Table 1. Events in the women's history that could increase the risk of HCV infection and characteristics of the group

\begin{tabular}{|l|c|c|}
\hline \multicolumn{1}{|c|}{ Risk event in the history } & Number of women & $\%$ \\
\hline Surgical procedure & 106 & 24.5 \\
\hline $\begin{array}{l}\text { Blood product transfusion } \\
\text { age of women } \\
\text { <24 years } \\
\text { 24-35 years } \\
\text { >35 years }\end{array}$ & 94 & 21.8 \\
\hline \begin{tabular}{l|c|} 
Multiple hospitalizations \\
Health care workers with \\
needlestick/scarification in history
\end{tabular} & $(8 / 37)$ & 17.1 \\
\hline Infected sexual partner & $(63 / 346)$ & $(18.2)$ \\
\hline Infected other family member & $(3 / 49)$ & $(6.1)$ \\
\hline Tattoo or piercing & 39 & 9.0 \\
\hline Mother infected with HCV & 11 & 5.6 \\
\hline Unknown source of infection & 5 & 2.5 \\
\hline Total & 5 & 1.2 \\
\hline
\end{tabular}

IVDU - intravenous drug use.
Based on the place of residence, we found a higher incidence of IVDU among urban residents compared with rural residents $(70 / 367$ (19.1\%) vs 4/61 (6.1\%); $\mathrm{p}=0.01)$. Information on the type, duration, and number of the doses of intravenous drugs was not collected, recognizing that even a single incidence of drug use with HCV-contaminated equipment carries a risk of $\mathrm{HCV}$ infection. Among the children of mothers with a history of IVDU, 25/74 (33.8\%) remained in foster care (adoption or orphanages), $49 / 74$ (66.2\%) were in the care of their mothers, $28 / 74$ of the mothers (37.8\%) declared abstinence, and $21 / 74$ of the mothers (28.4\%) participated in methadone programs.

The characteristics of anti-HCV-positive mothers stratified by intravenous drug use status are presented in Table 2.

In addition, the history of $\mathrm{HCV}$-infected women was analyzed for changes in risk events in the periods: 1998-2002, 2003-2009 and 2010-2012. We observed an increasing incidence of IVDU $(3.7 \%, 17.7 \%$ and $24.4 \%$, respectively; $\mathrm{p}=0.007)$ and decreasing history of blood transfusion among HCV infected women (31.5\%, 22.3\% and 12.8\% in the subsequent periods; $\mathrm{p}=0.03$ ). All of the blood transfusions leading to $\mathrm{HCV}$ infection in this study were performed prior to 1992.

An event with the probability of increasing the risk of $\mathrm{HCV}$ infection was not determined in 71/432 women (16.4\%), including 35/354 (9.9\%) from 1998 to 2009 and 36/78 (46.1\%) between 2010 and 2012 (p < 0.001).

The reasons for undergoing diagnostic tests are presented in Table 3.

In $77 / 432$ cases $(17.8 \%)$, tests were performed according to a planned gynecological recommendation before or during pregnancy. Changes in the responses in subsequent years are presented in Fig. 1.

The women were divided into 3 groups according to the time of HCV infection diagnosis: 287/432 (66.4\%) were

Table 2. Characteristics of anti-HCV-positive mothers stratified by intravenous drug-use status

\begin{tabular}{|c|c|c|c|}
\hline Characteristics of mothers & $\begin{array}{l}\text { Mothers without IV drug use; } \\
\qquad \begin{array}{c}n=358 \\
n(\%)\end{array}\end{array}$ & $\begin{array}{l}\text { Mothers with IV drug use; } n=74 \\
\qquad n(\%)\end{array}$ & $\begin{array}{l}\text { In total; } \\
n=432 \\
n(\%)\end{array}$ \\
\hline $\begin{array}{l}\text { Maternal hepatitis C RNA status* } \\
\text { HCV-RNA positive } \\
\text { HCV-RNA negative } \\
\text { HCV-RNA not done }\end{array}$ & $\begin{array}{l}191(53.4) \\
57(15.9) \\
110(30.7)\end{array}$ & $\begin{aligned} 50 & (67.6) \\
2 & (2.7) \\
22 & (29.7)\end{aligned}$ & $\begin{array}{l}241(55.8) \\
59(13.7) \\
132(30.5)\end{array}$ \\
\hline $\begin{array}{l}\text { Place of living } \\
\text { urban area } \\
\text { rural area }\end{array}$ & $\begin{array}{c}297(83.0) \\
61(17.0)\end{array}$ & $\begin{array}{c}70(94.6) \\
4(5.4)\end{array}$ & $\begin{array}{l}367(85.0) \\
65(15.0)\end{array}$ \\
\hline $\begin{array}{l}\text { Age of women } \\
<24 \text { years } \\
24-35 \text { years } \\
>35 \text { years }\end{array}$ & $\begin{array}{l}29(8.1) \\
283(79.1) \\
46(12.8)\end{array}$ & $\begin{array}{c}8(10.8) \\
63(85.1) \\
3(4.1)\end{array}$ & $\begin{array}{l}37(8.6) \\
346(80.1) \\
49(11.3)\end{array}$ \\
\hline $\begin{array}{l}\text { Time of HCV infection diagnosis } \\
\text { before pregnancy } \\
\text { during pregnancy } \\
\text { after parturition }\end{array}$ & $\begin{array}{c}238(66.5) \\
89(24.9) \\
31(8.6)\end{array}$ & $\begin{array}{l}49(66.2) \\
11(14.9) \\
14(18.9)\end{array}$ & $\begin{array}{l}287(66.4) \\
100(23.2) \\
45(10.4)\end{array}$ \\
\hline
\end{tabular}

*HCV-RNA status tested with RT PCR; P - NS for all comparisons; IV - intravenous; HCV-RNA - hepatitis C virus ribonucleic acid; RT-PCR - reverse transcription polymerase chain reaction. 


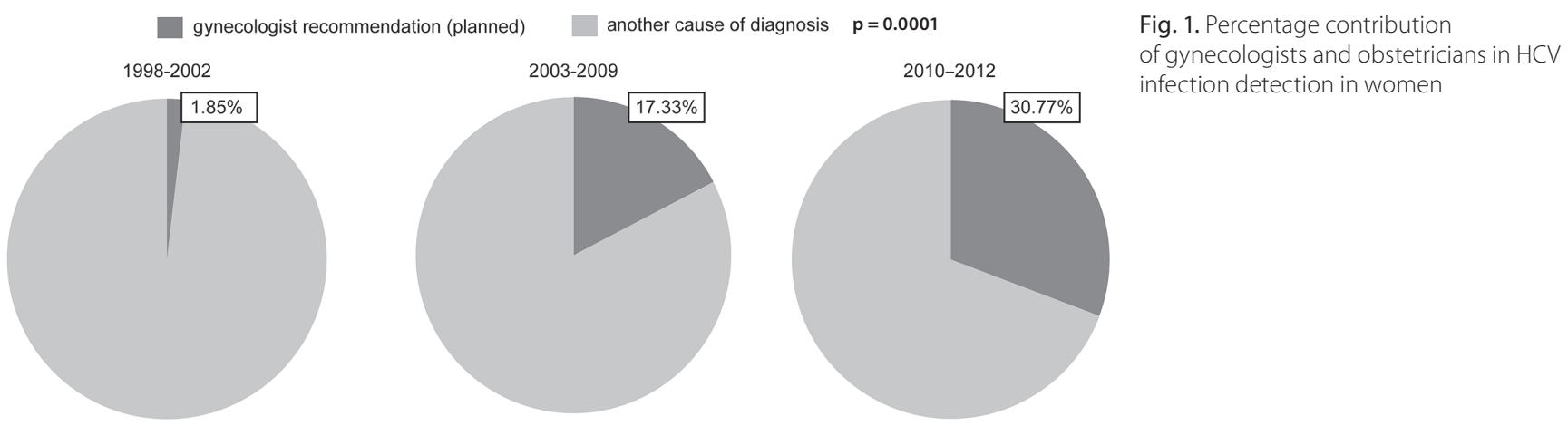

Table 3. Reasons for performing HCV diagnostics in women

\begin{tabular}{|l|c|c|}
\multicolumn{1}{|c|}{ Reason for HCV testing } & $\begin{array}{c}\text { Number } \\
\text { of women }\end{array}$ & $\%$ \\
\hline $\begin{array}{l}\text { Interview response (risk factor for HCV } \\
\text { infection in anamnesis) }\end{array}$ & 125 & 28.9 \\
\hline $\begin{array}{l}\text { Gynecologists' recommendation (planned, } \\
\text { without recognized risk factors in history) }\end{array}$ & 77 & 17.8 \\
\hline $\begin{array}{l}\text { Acute hepatitis C or other complaints } \\
\text { Blood donor examination }\end{array}$ & 48 & 11.1 \\
\hline $\begin{array}{l}\text { Increased aminotransferases activity } \\
\text { Obstetric cholestasis }\end{array}$ & 45 & 10.4 \\
\hline $\begin{array}{l}\text { Periodical examination of health care worker } \\
\text { or after occupational exposure }\end{array}$ & 29 & 10.2 \\
\hline $\begin{array}{l}\text { Detection of anti-HCV antibodies in child or } \\
\text { HCV-RNA in umbilical cord blood or placenta }\end{array}$ & 19 & 7.0 \\
\hline $\begin{array}{l}\text { During other examination } \\
\text { Examination at the patient's initiative }\end{array}$ & 11 & 2.6 \\
\hline \begin{tabular}{l} 
In total \\
\hline
\end{tabular}
\end{tabular}

HCV-RNA - hepatitis C virus ribonucleic acid.

diagnosed before pregnancy, 100/432 (23.1\%) were diagnosed during pregnancy, and 45/432 (10.4\%) were diagnosed after parturition. A comparison of the periods 1998-2009 and 2010-2012 showed that the proportion of women with diagnosed infection during pregnancy increased from $76 / 354$ (21.5\%) to $24 / 78$ (30.8\%), respectively.

\section{Discussion}

Complaints or abnormalities in laboratory tests (symptoms suggesting acute hepatitis, cholestasis during pregnancy, elevated aminotransferases, etc.) were the reasons for anti-HCV testing in $28.2 \%$ of the participants.

Specific interview responses or employment in health care services was the reason for testing in $35.6 \%$ of the cases (154/432) (Table 3). Extended and complementary interviews conducted during the survey were used to determine risk events in the women's histories in an additional 48\% of cases (207/432). Knowledge of the epidemiology of HCV infection specific to the given population and appropriately conducted interviews by the general practitioner were likely to increase the detection of $\mathrm{HCV}$ infection. ${ }^{8,9}$ Events that could carry a risk of HCV infection in the respondents' histories are presented in Table 1.

The most important changes in HCV sources in recent years are related to blood donation centers, with the safety of transfused blood products increasing significantly because of the introduction of $\mathrm{HCV}$ testing in blood donation centers in Poland (anti-HCV since 1992 and HCV-RNA RTPCR since 2001/2002). ${ }^{10,11}$ It is estimated that $1.4 \%$ of blood donors in Poland were anti-HCV(+) before the introduction of routine serological tests. ${ }^{12}$ All blood transfusions resulting in $\mathrm{HCV}$ infection in this study were performed prior to 1992. It is likely that a history of blood transfusion will not be a risk factor for HCV infection in women of reproductive age within 25 years.

Intravenous drug users represent a significant group among the HCV-infected population, and multiple exposures to $\mathrm{HCV}$ and a lower incidence of spontaneous HCV-RNA clearance are found among intravenous drug users. ${ }^{13-15}$ The prevalence of IVDU among the interviews of HCV-infected women increased from 3.7\% (1998$2002)$ to $17.7 \%$ (2003-2009) and to $24.4 \%$ (2010-2012) ( $\mathrm{p}=0.0075)$. Young women (under 24 years old) living in cities accounted for the majority of IVDU ( $p=0.01)$. From a reproductive health perspective, an increase in the percentage of teenagers reporting at least 1 contact with an intravenous drug is a worrisome problem; according to Sieroslawski, this percentage was $0.3-0.6 \%$ in 2003 and $0.6-1.2 \%$ in 2011 (higher in the group of 15- and 16-yearolds than in those aged $17-18$ years). ${ }^{16}$

A mother actively using drugs is not able to care for her child responsibly. Among children born to IVDU mothers, $33.8 \%$ remained in foster care and $66.2 \%$ remained in the care of mothers who reported abstinence or participation in a methadone program.

Determining a direct relationship between surgical procedures or multiple hospitalizations and HCV infection is difficult unless the patient presented with symptoms of acute hepatitis after a period corresponding to $\mathrm{HCV}$ incubation. ${ }^{4}$ Such time-dependence was not demonstrated in any of the women; thus, it is likely that hospitalizations in most of these cases had no effect on HCV infection. However, the data for these women should be analyzed against a control group with no risk factors. 
Health care workers may be a group with an increased risk for HCV infection. ${ }^{4,17-20}$ The risk of infection after incidental occupational exposure is less than $2 \%$ on average (range $0-10 \%)$. Flisiak et al. analyzed the presence of anti-HCV among health care workers in Poland and found significant differences depending on the workplace, with anti-HCV detected in $0.98 \%$ of basic health care employees, in $2 \%$ of employees in multi-profile hospitals, and in $3.28 \%$ of employees in specialist centers. ${ }^{21}$ All of the $\mathrm{HCV}$-infected health care workers in our study confirmed that they had been stabbed with a needle or sharp instrument while dealing with a patient.

Postgraduate training in HCV epidemiology may improve the effectiveness of HCV detection, and such courses for gynecologists and obstetricians led to the following results: among women examined from 1998 to 2002, HCV infection was diagnosed based on gynecologists' recommendations in $1.8 \%$ of cases, whereas in 2003-2009 HCV infection was diagnosed based on gynecologists' recommendations in $17.3 \%$ of cases (Fig. 1). A further statistically significant $(\mathrm{p}<0.001)$ increase in gynecologist involvement in HCV diagnosis after the year 2010 (30.77\%) was related to the implementation of the Act on Pregnant Woman Care, which recommends anti-HCV examinations for all pregnant women in Poland. ${ }^{22}$ This act also led to an increase in the percentage of women diagnosed during pregnancy after 2010.

There is a large group of women for whom infection was only detectable because of screening examinations. The introduction of screening recommendations for pregnant women in 2010 led to an increase in the percentage of HCV infections detected in women who did not disclose risk factors in an interview (9.9\% before 2010 vs $46.1 \%$ after 2010; ( $<$ 0.001). Certain women may not disclose risk factors in their history for reasons of moral and social censure. A study by Lamber et al. determined that infection risk factors were not observed for $27 \%$ of Irish women infected with $\mathrm{HCV}$, over half of whom were immigrants from Eastern Europe. ${ }^{6}$ In an examination of pregnant women in Austria, Diab-Elschahawi found that 21\% of them learned about their infection from a screening examination, despite a lack of risk factors. ${ }^{23}$

A significant number of women of reproductive age who are infected with $\mathrm{HCV}$ are unaware of their infection and will not qualify for examination because of a lack of disclosed risk factors or clinical abnormalities. This group may only be detected through screening examinations. ${ }^{24,25}$ In our study, 36.1\% of women were diagnosed without presenting risk factors in the interview, physical examination, or laboratory results.

Because of its cost-effectiveness, universal/antenatal screening is primarily considered in populations in which the prevalence of anti-HCV is higher than $1-2 \% .{ }^{24,26,27}$ Such rates of infection significantly increase the risk of contact with HCV through casual sexual contact and non-sterile medical and non-medical procedures. Currently, the United States has implemented a routine examination for anti-HCV in people born 1945-1965, regardless of other risk factors. Anti-HCV antibodies are detected in 3.5\% of people in this group age, with the estimated average for the whole population at $1-1.5 \% .^{28}$ The prevalence of anti$\mathrm{HCV}$ in Europe is in the range of $0.4-5.2 \%$ and Flisiak estimated the prevalence in Poland at $1.9 \% .^{5,21}$

The most beneficial method of reducing the risk of vertical infection is to detect infection in the pre-reproduction period and to use antiviral therapy to eliminate or reduce $\mathrm{HCV}$ viraemia. ${ }^{29-31}$ Because of toxicity, drug therapies that are applicable during pregnancy are not available. ${ }^{4}$

Among the women included in the study, 287/432 (66.4\%) knew of their infection prior to pregnancy, whereas the remaining participants (145/432 (33.6\%)) did not. The results of this study confirm the low awareness of HCV infection, which is consistent with findings from studies conducted among various European populations. ${ }^{23,32}$ The data presented here suggests the benefits of performing screening examinations for HCV infection in young women of reproductive age, although detecting infection during pregnancy also has benefits. For example, therapy is more effective when performed shortly after birth because of changes in the immune system, ${ }^{33,34}$ effective therapy provides benefits for subsequent pregnancies, and maternal infection awareness programs provide recommendations on slowing the course of the disease, such as avoiding alcohol and receiving vaccinations against other hepatotropic viruses (HAV, HBV). Detecting HCV infection in mothers will promote diagnostic testing in their children, and children infected with $\mathrm{HCV}$ will benefit from early treatment. ${ }^{24}$

The authors are aware of the following study limitations: 1. the group of women infected with HCV was not selected from the population based on screening examinations, and 2 . the study group was not uniform and included respondents who were anti-HCV+, though $\mathrm{HCV}$ replication was not confirmed in all cases. (It is estimated that an active replication of the virus occurs in $31 \%$ of Polish anti$\mathrm{HCV}(+)$ individuals on average, with $44 \%$ of cases occurring in patients $<25$ years old and $27 \%$ of cases occurring in patients $>40$ years old). ${ }^{21}$

Although the authors have acknowledged these limitations, they believe that the study presents new information on HCV infection among women of reproductive age in Poland. To our knowledge, this is the only work of this type concerning women in Poland.

\section{Conclusions}

Establishing $\mathrm{HCV}$ infection risk factors by analyzing interview responses is the most common indicator for serological testing. However, performing examinations on women according to their interview responses alone will not lead to a diagnosis of all infected cases. Screening for anti-HCV in pregnant women increases the detection of $\mathrm{HCV}$ infection in this group. Universal screening of women of reproductive age should be considered. 


\section{References}

1. Gower E, Estes C, Blach S, Razavi-Shearer K, Razavi H. Global epidemiology and genotype distribution of the hepatitis $C$ virus infection. J Hepatol. 2014;61:45-57.

2. Zaltron S, Spinetti A, Biasi L, Baiguera C, Castelli F. Chronic HCV infection: Epidemiological and clinical relevance. BMCInfect Dis. 2012;12:1-7.

3. Terrault NA. Sexual activity as a risk factor for hepatitis C. Hepatology. 2002;36:99-105.

4. Boesecke $\mathrm{CH}$, Wasmuth J-CH. Hepatitis C. In: Mauss S, Berg T, Rockstroh J, Sarrazin C, Wedemeyer H, eds. Hepatology: A Clinical Textbook. $5^{\text {th }}$ ed. Flying Publisher 2014:50.

5. Hahné SJM, Veldhuijzen IK, Wiessing L, Lim TA, Salminen M, van de Laar M. Infection with hepatitis B and C virus in Europe: A systematic review of prevalence and cost-effectiveness of screening. BMC Infect Dis. 2013;13:1-16.

6. Lamber J, Jackson V, Coulter-Smith S, et al. Universal antenatal screening for hepatitis C. Ir Med J. 2013;106:136-139.

7. Pembrey L, Newell ML, Tovo PA, et al. The management of HCV infected pregnant women and their children European paediatric HCV network. J Hepatol. 2005;43:515-525.

8. Wong HK, Lee CK, Leung JN, Tsoi WC, Lin CK. Risk factor analysis of hepatitis $C$ virus infection among Chinese blood donors in Hong Kong. Transfus Med. 2012;22:133-136.

9. Vilibic-Cavlek T, Kucinar J, Kaic B, et al. Epidemiology of hepatitis C in Croatia in the European context. World J Gastroenterol. 2015;21: 9476-9493.

10. Esteban Jl, Sauleda S, Quer J. The changing epidemiology of hepatitis C virus infection in Europe. J Hepatol. 2008;48:148-162.

11. Brojer E. Serological and molecular markers of HCV infection in Polish blood donor. Przegl Epidemiol. 2005;59:511-517.

12. Moraczewska Z, Maria M, Brojer E, Medyńska J, Seyfried H, Żupańska B. RNA HCV detection in Polish blood donors and in plasma derivatives. Acta Haematol Pol. 2000;31:391-397.

13. Act of 29 July 2005 on drug addiction counteracting; 2005. http:// isap.sejm.gov.pl/DetailsServlet?id=WDU20051791485. Accessed August 30, 2015.

14. Czapliński J, Panek T. Social diagnosis 2011. Conditions and quality of life of Polish citizens. Report. Warszawa: 2011.

15. Micallef JM, Macdonald V, Jauncey M, et al. High incidence of hepatitis $C$ virus reinfection within a cohort of injecting drug users. J Viral Hepat. 2007;14:413-418.

16. Sieroslawski J. Alcohol and drugs using by school youths. Report from national questionnaire survey realized in 2011. Warszawa: 2011

17. Westermann C, Peters C, Lisiak B, Lamberti M, Nienhaus A. The prevalence of hepatitis $C$ among healthcare workers: A systematic review and meta-analysis. Occup Environ Med. 2015;72:880-888.

18. Bilski B, Wysocki J, Hemerling M. Viral hepatitis in health service workers in the Province of Wielkopolska. Int J Occup Med Env Heal. 2002;15:347-352.
19. Bilski B. Viral hepatitis as an occupational disease in Poland. Hepat Mon. 2011;11:539-543.

20. Yazdanpanah Y, De Carli G, Migueres B, et al. Risk factors for hepatitis $C$ virus transmission to health care workers after occupational exposure: A European case-control study. Clin Infect Dis. 2005;54 Spec No:1S23-1S31.

21. Flisiak R, Halota W, Horban A, Juszczyk J, Pawlowska M, Simon K. Prevalence and risk factors of HCV infection in Poland. Eur J Gastroenterol Hepatol. 2011;23:1213-1217.

22. Regulation of the Minister of Health of 23.09.2010 on standards and medical procedures in medical health services in the range of perinatal care over the woman during physiological pregnancy, physiological birth, postnatal period and infant care; 2010. http://isap. sejm.gov.pl/DetailsServlet?id=WDU20101871259. Accessed October 7, 2010.

23. Diab-Elschahawi M, Dosch V, Honsig C, et al. Evaluation of a universal vs a targeted hepatitis $C$ virus screening strategy among pregnant women at the Vienna University Hospital. Am J Infect Control. 2013;41:459-460.

24. Urbanus AT, van Keep M, Matser AA, et al. Is adding HCV screening to the Antenatal National Screening Program in Amsterdam, The Netherlands, cost-effective? PLoS One. 2013;8:1-9.

25. Kumar A, Aparma Sharma K, Gupta R, Kar P, Chakravarti A. Prevalence and risk factors for hepatitis $C$ among pregnant women. Indian J Med Res. 2007;125:211-215.

26. Ward C, Tudor-Williams G, Cotzias T, Hargreaves S, Regan L, Foster GR. Prevalence of hepatitis $C$ among pregnant women attending an inner London obstetric department: Uptake and acceptability of named antenatal testing. Gut. 2000;47:277-280.

27. McDermott CD, Moravac CC, Yudin MH. The effectiveness of screening for hepatitis C in pregnancy. J Obstet Gynaecol Canada. 2010;32: 1035-1041.

28. Smith BD, Morgan RL, Beckett GA, et al. Recommendations for the identification of chronic hepatitis $C$ virus infection among persons born during 1945-1965. MMWR Recomm Rep. 2012;61(RR-4):1-32.

29. Aniszewska M, Kowalik-Mikołajewska B, Pokorska-Lis M, Kalinowska M, Marczyńska M. Mother-to-infant HCV transmission. Can we influence the frequency and the course of the infection? Przegl Lek. 2010;67(1):9-1.

30. Floreani A. Hepatitis C and pregnancy. World J Gastroenterol. 2013;19: 6714-6720.

31. Kołakowska A, Godzik P, Madaliński K. HCV infection in pregnancy. Med Dosw Mikrobiol. 2014;66:215-222.

32. Guttierez-Zufiaurre N, Sanches-Hernandez J, Munoz S. Seroprevalence of antibodies against Treponema pallidum, Toxoplasma gondii, Rubella virus, hepatitis B and C virus and HIV in pregnant women. Enferm Infecc Microbiol Clin. 2004;22:512-516.

33. Lin $\mathrm{HH}, \mathrm{KaO} \mathrm{JH}$. Hepatitis $\mathrm{C}$ virus load during pregnancy and puerperium. BJOG. 2000;107:1503-1506.

34. Irshad M, Khushboo I, Singh S, Singh S. Hepatitis C virus (HCV): A review of immunological aspects. Int Rev Immunol. 2008;27:497-517. 